\title{
KADAR VITAMIN C CABAI RAWIT (Capsicum frutescens L) HASIL OZONASI SELAMA PENYIMPANAN SUHU RUANG
}

\author{
Mutia Aryanti Tatengkeng, Imas Siti Setiasih, Debby M Sumanti \\ Program Studi Teknologi Pangan, Fakultas Teknologi Industri Pertanian, \\ Universitas Padjadjaran, J1. Raya Jatinangor KM 21, Sumedang 45363, Indonesia \\ Email : aryantimutia.ma@gmail.com
}

\begin{abstract}
Abstrak
Penyimpanan cabai rawit dapat memudahkan cabai mengalami kerusakan sehingga akan mempengaruhi karakteristik fisik dan karakteristik lainnya yang akan menyebabkan penurunan mutu. Penelitian ini bertujuan untuk mengetahui pengaruh ozonasi terhadap kadar vitamin C cabai rawit yang disimpan pada suhu ruang selama 10 hari. Metode yang digunakan adalah eksperimental dan dianalisis menggunakan regresi. Percobaan terdiri dari 2 perlakuan, yaitu tanpa ozonasi dan ozonasi pada konsentrasi 1 ppm. Analisis dilakukan selama 10 hari dalam interval waktu analisis setiap 2 hari. Hasil penelitian menunjukkan bahwa ozonasi dapat menghambat penurunan kadar vitamin $\mathrm{C}$.
\end{abstract}

\begin{abstract}
Storage of cayenne pepper can ease the chilli damage so that it will affect the physical characteristic and other characteristic that will lead to a decrease in quality. This research aims to determine the amount of vitamin $C$ of the ceyenne pepper with or without ozonation results during 10 days of storage. The methods used in this research is experimental methods which is followed by regression analysis. The trial it self consist of two handlings which are without ozonation and with ozonation on 1 ppm concentration. The analysis is conducted in 10 days with the interval of every two days. The results showed that ozonation process could inhibit levels of vitamin $C$.
\end{abstract}

Keywords : Ceyenne pepper; ozonation; vitamin C.

\section{Pendahuluan}

Cabai rawit merupakan salah satu tanaman hortikultura yang cukup potensial perkembangannya di sektor pertanian Indonesia dan bernilai ekonomis tinggi. Sifat cabai yang tidak dapat disimpan dalam waktu lama menjadi salah satu faktor tingginya nilai ekonomi tersebut karena masa simpan cabai rawit yang pendek sangat berpengaruh dalam proses pendistribusian dan menyebabkan kerugian pada petani (Rahman, 2010). Pendeknya masa simpan cabai rawit dikarenakan memiliki kadar air sebanyak $70 \%$ sehingga termasuk sebagai salah satu komoditas yang mudah rusak atau busuk dan susut (Rukmana, 2002). Cabai rawit dapat bertahan $2-3$ hari jika disimpan pada suhu ruang dan selanjutnya akan mengalami penurunan mutu.

Berdasarkan kandungan kalori dan nutrisi, didapatkan bahwa vitamin $\mathrm{C}$ dan vitamin A pada cabai rawit segar lebih banyak dari cabai rawit kering, dan menurut Alif (2017), cabai rawit dapat memenuhi kebutuhan vitamin C sebanyak $24 \%$ dari asupan harian yang disarankan, vitamin A 32\% dari asupan harian yang disarankan, zat besi 3\% dari asupan harian yang disarankan, dan kalsium sebanyak $7 \%$ dari asupan harian yang disarankan.
Cabai rawit yang diperdagangkan dalam bentuk segar memerlukan penanganan dan pengendalian yang dapat mengendalikan proses fisiologisnya. Salah satu usaha yang sedang berkembang mengenai penanganan bahan pangan segar saat ini adalah ozonasi (Khadre, Yousef, dan Kim, 2001). Ozonasi merupakan aplikasi ozon dalam bahan, dapat berbentuk gas maupun larutan. Ozon $\left(\mathrm{O}_{3}\right)$ dikenal sebagai salah satu sanitizer yang paling kuat dan dianggap efektif sebagai desinfektan. Ozon merupakan oksidator kuat yang dapat dimanfaatkan untuk membunuh bakteri, memudarkan warna, mengurangi bau, dan menguraikan senyawa organik (Beltrand dan Fernando, 1995).

Beberapa penelitian mengenai ozon telah dilakukan sebelumnya. Menurut Setiasih dkk (2012), air berozon dengan konsentrasi 1,9 ppm dan lama perendaman 5 menit pada kubis bunga diolah minimal (KBDM) memberikan hasil berupa tampilan fisik yang baik serta dapat menurunkan kandungan mikrobiologi pada kubis bunga diolah minimal. Penelitian lain yang dilakukan oleh Asgar dkk (2015), perlakuan pencucian dengan air berozon pada konsentrasi 1 ppm dapat membuat 
warna cabai merah lebih cerah dari yang tidak dilakukan pencucian dengan ozon.

Menurut Perez et al. (1999) dalam Asgar (2017), perlakuan ozon terhadap stroberi setelah penyimpanan selama 4 hari pada suhu $20^{\circ} \mathrm{C}$ menunjukkan perbedaan yang nyata dalam gula dan asam. Pada akhir penyimpanan yang diberi perlakuan ozon dengan suhu dingin kandungan vitamin $\mathrm{C}$ meningkat tiga kali dari kontrol. Hal ini diduga adanya pengaruh suhu terhadap laju respirasi, yaitu semakin rendah suhu maka semakin rendah respirasinya sehingga vitamin $\mathrm{C}$ yang terurai sedikit.

Berdasarkan kajian diatas, maka diperlukan penelitian untuk mengetahui pengaruh ozonasi terhadap kadar vitamin C cabai rawit yang disimpan pada suhu ruang.

\section{Metode Penelitian}

Langkah awal penelitian adalah dilakukannya preparasi sampel berupa pemanenan bahan yaitu cabai rawit varietas Domba dari perkebunan cabai Langensari, Lembang. Dilakukan sortasi, kemudian cabai rawit ditimbang 250 gram. Setelah itu dilakukan proses ozonasi selama 3 menit dan ditahan selama 2 menit lalu dikeringkan dan dikemas. Penyimpanan dilakukan selama 10 hari pada suhu ruang.

Pengujian kadar vitamin $\mathrm{C}$ dilakukan dengan menggunakan metode titrasi (AOAC, 2005). Cabai rawit ditimbang sebanyak 10 gram yang sebelumnya dihaluskan, kemudian dilarutkan dalam $100 \mathrm{ml}$ aquades. Dilakukan penyaringan kemudian dipipet $10 \mathrm{ml}$ filtrat ke dalam erlenmeyer dan ditambahkan $2 \mathrm{ml}$ amilum $1 \%$. Titrasi dilakukan dengan larutan iodium $0,01 \mathrm{~N}$ sampai terbentuk warna biru kehitaman. Penentuan kadar vitamin $\mathrm{C}$ dapat menggunakan rumus berikut:

$$
\frac{\text { Vol.iodium } \times m g \text { Asam askorbat }\left(\frac{m g}{m l}\right) \times F P}{\text { Massa sampel }(g)}
$$

Metode yang digunakan adalah metode eksperimental dengan 2 kali ulangan yang dilanjutkan dengan analisis regresi, dimana variabel (x) adalah lama penyimpanan dan variabel (y) merupakan hasil pengamatan berupa kadar vitamin C. Adapun rincian perlakuan tersebut :

Perlakuan A = cabai rawit tanpa ozonasi

Perlakuan $\mathrm{B}=$ cabai rawit hasil ozonasi pada konsentrasi 1 ppm

\section{Hasil dan Pembahasan}

Berdasarkan analisis statistik, dapat diketahui hubungan antara lama penyimpanan dengan kadar vitamin $\mathrm{C}$ adalah linier seperti pada Gambar 1.

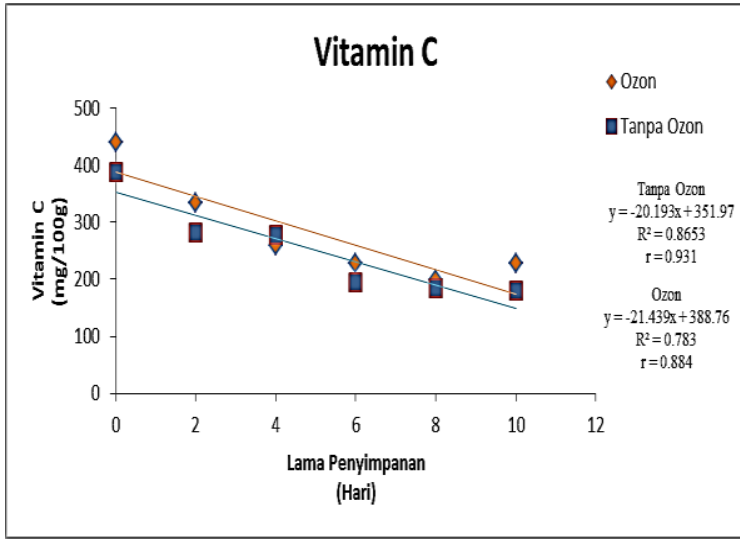

Gambar 1. Grafik Hubungan Lama Penyimpanan terhadap Kadar Vitamin C Cabai Rawit

Berdasarkan grafik tersebut diketahui bahwa kadar vitamin $\mathrm{C}$ pada cabai rawit hasil ozonasi memiliki hasil lebih tinggi dari tanpa ozon, yaitu 440,628 mg/100g, sedangkan tanpa ozon $388,159 \mathrm{mg} / 100 \mathrm{~g}$. Kadar vitamin C mengalami penurunan selama penyimpanan, namun pada perlakuan tanpa ozonasi terjadi kenaikan pada pengujian hari keempat lalu turun kembali seiring dengan lama penyimpanan. Sementara pada cabai dengan perlakuan ozonasi, terdapat kenaikan kadar vitamin $\mathrm{C}$ pada pengujian hari kesepuluh.

Kedua persamaan tersebut menunjukkan bahwa nilai koefisien regresi < 0 , yaitu $-20,193$ pada cabai rawit tanpa perlakuan ozonasi dan sebesar -21,439 pada cabai rawit hasil ozonasi yang berarti hubungan antara lama penyimpanan cabai rawit baik dengan perlakuan ozonasi maupun tanpa ozonasi terhadap kadar vitamin $\mathrm{C}$ pada cabai rawit bersifat linier negatif. Hal ini berarti selama 10 hari penyimpanan, terdapat kecenderungan bahwa kadar vitamin $C$ cabai rawit akan menurun setiap 2 hari penyimpanan. Menurut Ramaswamy et al., (2007), ozon bereaksi dengan komponen sel yang mudah teroksidasi, terutama komponen sel yang mengandung ikatan rangkap, gugus sulfhidril dan cincin fenolat, sehingga reaksi ozon dengan komponen sel ini mengakibatkan sel menjadi rusak dan komponen sel terurai lebih lanjut menjadi senyawa lebih sederhana. Aktivitas ozon sebagai pengoksidasi kuat tampak jelas dengan penurunan kadar vitamin $\mathrm{C}$ buah. Sifat vitamin $\mathrm{C}$ yang mudah teroksidasi mendukung penurunan yang nyata kadar vitamin $\mathrm{C}$ cabai rawit yang direndam dengan air berozon dan tanpa perendaman air berozon.

Berdasarkan hasil analisis ANOVA untuk variabel lama penyimpanan dengan parameter kadar vitamin $\mathrm{C}$ cabai rawit, diperoleh Fhitung = 14,389 dan Ftabel = 7,708. Oleh karena F hitung > F tabel maka hipotesis nol ditolak dan hipotesis satu diterima, yaitu adanya pengaruh yang signifikan antara lama penyimpanan dengan 
kandungan vitamin C. Tingkat kepercayaan persamaan linear antara lama penyimpanan dengan kadar vitamin $\mathrm{C}$ pada cabai rawit tanpa ozonasi dan hasil ozonasi ditunjukkan dengan nilai $\mathrm{R}^{2}$ sebesar $86,5 \%$ dan $78,3 \%$ vitamin $\mathrm{C}$ dipengaruhi oleh lama penyimpanan sedangkan sisanya dipengaruhi faktor lain. Faktor lain yang mempengaruhi perubahan kandungan vitamin $\mathrm{C}$ cabai rawit selama penyimpanan diantaranya adalah jenis kemasan, kelarutan vitamin C, kondisi penyimpanan, serta ketersediaan oksigen. Menurut Muchtadi (2010), vitamin $\mathrm{C}$ merupakan jenis vitamin yang tidak stabil karena mudah teroksidasi, mudah rusak yang disebabkan oleh cahaya dan juga suhu tinggi selama penyimpanan. Hal tersebut diperkuat oleh Cithravhanti et al., (2015) yang menyatakan bahwa semakin lama waktu penyimpanan, maka kadar vitamin $\mathrm{C}$ akan semakin menurun. Penurunan yang terjadi disebabkan oleh proses oksidatif, yang dirangsang oleh cahaya, oksigen, panas, peroksida dan ezim, seperti askorbat peroksidase. bahwa :

Berdasarkan penelitian dapat disimpulkan

1. Semakin lama penyimpanan yang dilakukan, maka semakin sedikit kadar vitamin $\mathrm{C}$ yang terkandung dalam cabai rawit.

2. Perlakuan ozonasi dapat meningkatkan kadar vitamin $\mathrm{C}$ pada cabai rawit.

3. Kadar vitamin $\mathrm{C}$ pada cabai rawit hasil ozonasi selama 10 hari penyimpanan adalah $227,574 \mathrm{mg} / 100 \mathrm{~g}$

4. Kadar vitamin C pada cabai rawit tanpa ozonasi selama 10 hari penyimpanan adalah $180,098 \mathrm{mg} / 100 \mathrm{~g}$.

\section{Daftar Pustaka}

1. AOAC. 2005. Official Method of Analysis of The Association of Official Analytical Chemist. AOAC. Washington DC.

2. Asgar, A., Musaddad, D., Setyabudi, D., dan Hassan, H. 2015. Teknologi Ozonasi Untuk Mempertahankan Kesegaran Cabai Cultivar Kencana Selama Penyimpanan. Jurnal Penelitian Pascapanen Pertanian Vol. 12 No. 1 : 20-26.

3. Asgar, A., Musaddad, D., dan Rahmat S. 2017. Pengaruh Ozonasi dan Kemasan untuk Mereduksi Residu Pestisida dan Mempertahankan Karakteristik Kesegaran Cabai Merah dalam Penyimpanan. Jurnal Hortikultura Vol. 27 No. 2 : 241-252.

4. Beltrand, J Fernando. 1995. Ozone Reaction Kinetic for Water and Wastewater System. CRC Press Company. Washington DC.

5. Chitravathi, K., Chauhan OP., Raju P S. 2015. Influence of Modified Atmosphere Packaging on Shelf-life of Green Chillies
(Capsicum annuum L.). Food Packaging and Shelf Life 45 : 1-9.

6. Khadre, M. A., A. E. Yousef, dan J. G. Kim. 2001. Microbiological Aspects of Ozone Applications in Food: A Review. Journal of Food Science 66(9): 1242-1252.

7. M, Alif. S. 2017. Kiat Sukses Budidaya Cabai Rawit. Bio Genesis. Yogyakarta.

8. Muchtadi, T. R. 2010. Ilmu Pengetahuan Bahan Pangan. Alfabeta, Bandung.

9. Rahman, S. 2010. Meraup Untung Bertanam Cabai Rawit dengan Polybag. ISBN : 978-979-29-1602-7. Lily Publisher. Yogyakarta.

10. Ramaswamy, R., L Rodiguez-Romo., M Vurma., V. M. Balasubraniam and A.E. Yousef. 2007. Ozone Technology: Fact Sheet for Food Processor. The Ohio State University Extention. Available at: http//www.fst.osu.edu/foodsafetylab/index.ht $\mathrm{ml}$ (Diakses pada Tanggal 27 November 2018).

11. Rukmana, R. 2002. Usaha Tani Cabai Rawit. Kanisius. Yogyakarta.

12. Setiasih, I.S., R. Kastaman, D, Musaddad dan I. Hanidah. 2012. Aplikasi Ozon, Pengemas Plastik dan Suhu Rendah pada Kubis Bunga Fresh-Cut untuk Menghasilkan Produk Siap Guna Yang Aman dan Bermutu. Laporan Akhir Penelitian Strategis Nasional. FTIP Universitas Padjadjaran. Bandung. 